\title{
MEMORY STUDIES IN ELECTRIC CONVULSION THERAPY II. THE PERSISTENCE OF VERBAL RESPONSE PATTERNS

\author{
BY
}

\author{
MOYRA WILLIAMS
}

\author{
From the Research Department, Graylingwell Hospital, Chichester
}

In a previous study of memory for ambiguous pictures shown to patients immediately before and after electro-convulsive therapy, (E.C.T.), it was found that although in the post-E.C.T. confusional state the pictures were regarded by the patients as unfamiliar, those which had been seen and correctly named by them before the treatment were recognized with fewer cues than might be expected (Williams, 1950). Thus, despite the absence of both recall and recognition on the part of the subjects, the effect of previous exposure to a stimulus was apparent in the experimental situation. From the verbal responses given by the patients, however, and the sequence in which these were obtained, it seemed likely that the names and descriptions given were in the nature of automatic responses and did not include conscious recognition of the material in its fuller sense. An experiment by Zubin (1942), which showed that learning of paired associates immediately before E.C.T. impeded, through perseveration, post-treatment learning of new associates to the same stimulus words, also indicates that modes of verbal response established before the treatment are not easily disrupted. The same author (Zubin, 1948) observed in a woman patient recognition above the chance expectation of material memorized by her before shock, despite her protest that she had never seen it before. From these two observations Zubin concludes that after E.C.T. " though the memory trace itself is retained, awareness of the memory is completely lost". This statement accords with Gillespie's (1937) distinction between two types of recall (1) sensorymotor recall, and (2) voluntary recall, including associations.

It was in order to test the hypothesis that these two types of memory might be distinguished on account of one type being less seriously affected by E.C.T. than the other that the following experiment was carried out.

\section{Method}

Test Material and Administration.-The test material consisted of two groups of pictures (Fig. 1). Those in the first group were straightforward pictures of simple objects drawn in black ink on white cards 2 in. $\times 1$ in. Those in the second group were of a sketchy nature, each representing vaguely one of the objects in Group I. The pictures in Group I will be referred to as " things" and those in Group II as "half-things". Before beginning the test the subjects were instructed as follows : "I want to see how quick you can be. I have some small pictures here; some of them you will recognize without any difficulty, but some of them are not quite so easy. I am going to hold them up one at a time, and I want you to see how quickly you can tell me what the pictures are or what they look like to you. It does not matter what you call them. The idea is just to see how. quickly you can put a name to them." A stop-watch was started as soon as the picture was held up and the patient's attention focused on it. It was stopped directly the patient began to give an answer, and without waiting until mention of the specific name. Thus, ifo the patient's verbal response was, "I suppose it might be a tree", his reaction-time was measured from the moment he started speaking (at which time it was concluded that the concept tree was formed in his mind) and not from his mention of the word tree. Patients who found difficulty in naming the "half-things" were given further encouragement with such questions as, "What is it most like?"; "What could it be ?"; " How would you describe it to someone sitting behind you ?" until 30 seconds had elapsed. After this time if no response, or only unacceptable responses, had been given, a failure was recorded.

Scoring.-Scoring was made in terms of reaction-time scored to the nearest half-second. All descriptions of the "half-things" were scored as acceptable, if they had any relation to the stimulus. The majority of "halfthings" were taken to represent the corresponding concrete objects in Group I.

Population.-The subjects in the experiment were 58 patients, including both men and women, at Graylingwell Hospital, of whom 46 were at the time of examination undergoing a course of E.C.T. Among the patients under this form of treatment, the clinical diagnosis, the time of admission to hospital, the length of treatment, age, I.Q. and personality integration, varied, but in most cases depression was the outstanding symptom for which treatment had been instigated. Only those 

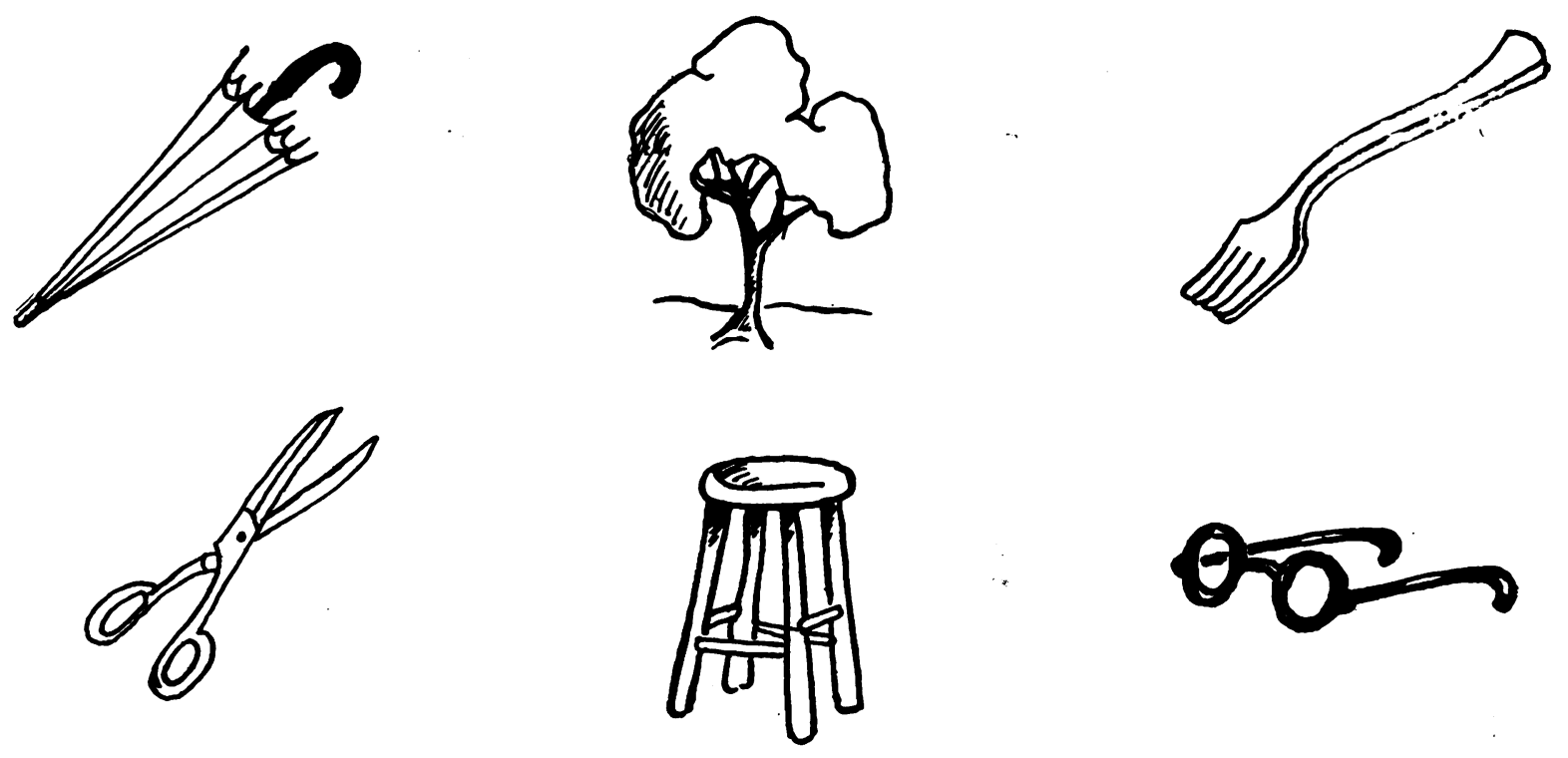

Group 1
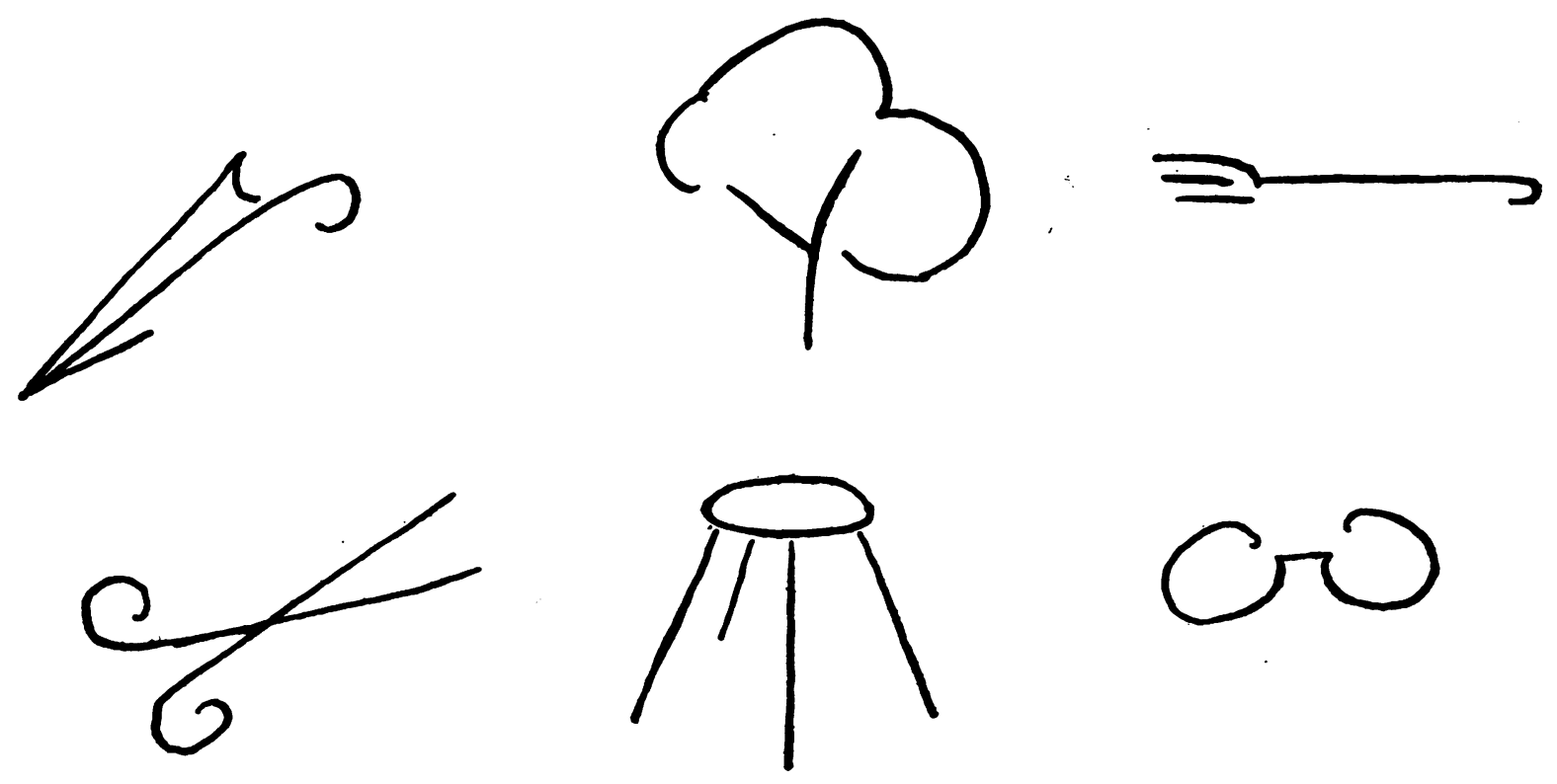

Group 2

Fig. 1.-The "things" (Group 1) and "half-things" (Group 2) used in the test. 
patients who were in a well-orientated condition and could name a picture similar to any of the "things" in under 30 seconds were used as subjects. Thus patients with gross perceptual disturbances or very marked retardation before treatment were not included in the experiment. Brief stimulus E.C.T. was given without sedation or curare in all cases. The remaining 12 patients were selected to match those undergoing E.C.T. as closely as possible in respect of clinical diagnosis, age, I.Q. and time of admission to hospital. Many of them began to receive E.C.T. shortly after they had taken part in this experiment.

Experimental Procedure.-The total number of subjects was divided into five matched groups: four groups of subjects under treatment, and one control group. The experimental procedure was slightly varied for each group as shown below.

Group I (Ten Patients undergoing E.C.T.).-The subjects were shown three "things" some time during the day before treatment was given, and all six " half-things" in the post-E.C.T. confusional period. (This period was defined as the time before the patient's memory for the examiner or the previous test had returned but when he was able to count the number of fingers held up before him, and correctly name keys, stop-watch, and pen. The exact time after treatment varied from one patient to another.)

Group IIa (Nine Patients undergoing E.C.T.).-The subjects were shown three " half-things" before E.C.T., and all six " half-things" in the post-E.C.T. confusional period.

Group IIb (Eight Patients undergoing E.C.T.).-The subjects were shown three "half-things" before E.C.T. In the post-E.C.T. confusional period they were first shown three irrelevant "things" and then all six "halfthings".
Group III (Ten Patients undergoing E.C.T.).-The subjects were shown three " half-things" before E.C.T. In the post-E.C.T. confusional period they were first shown the three "things" corresponding to the unseen "half-things" and then all six " half-things".

Group IV (Nine Patients undergoing E.C.T.).-The subjects were not shown any of the experimental pictures before E.C.T. During the post-E.C.T. confusional period they were first shown three "things " and then all six " half-things".

Group V(Twelve Patients not undergoing E.C.T.).-The subjects were first shown three "things" and then all six " half-things".

The procedure followed with each group is set out schematically in Table I. The order in which " things" and "half-things" was shown was continually varied in order to compensate for possible differences in the recognizability of the material itself, so that in Table I $a, b$, and $c$ refer to the first pictures shown and not to any particular " things" or "half-thing". Thus, if one patient in Group I was shown the umbrella, the stool, and the glasses, before treatment, the next patient in this group was shown the tree, fork, and scissors at this time. During the post-E.C.T. testing a familiar picture was shown alternately with an unfamiliar one. The subjects in Groups III, IV, and V, however, were shown each " thing" picture some time, but not immediately, before its corresponding " half-thing ".

\section{Results}

The number of successful and unsuccessful responses to the "half-things" given in the postE.C.T. confusional state by the subject in each group and to each type of stimulus is given in Table II. The mean reaction-time for the successful responses and the value of $\chi^{2}$ between successes

TABLE I

SCHEME OF PROCEDURE

\begin{tabular}{|c|c|c|c|c|}
\hline \multirow{2}{*}{ Group } & \multicolumn{2}{|c|}{ Pre-E.C.T. } & \multicolumn{2}{|c|}{ Post-E.C.T. } \\
\hline & First Test & Second Test & First Test & Second Test \\
\hline I & $\begin{array}{c}\text { "Things" } \\
\mathrm{a}, \mathrm{b}, \mathrm{c}\end{array}$ & - & $\begin{array}{c}\text { "Half-things" } \\
\text { a-f }\end{array}$ & 一 \\
\hline IIa & $\begin{array}{c}\text { "Half-things" } \\
\text { a, b, c }\end{array}$ & - & - & $\begin{array}{c}\text { "Half-things" } \\
\text { a-f }\end{array}$ \\
\hline IIb & $\begin{array}{c}\text { "Half-things" } \\
\text { a, b, c }\end{array}$ & - & $\begin{array}{l}\text { "Things" } \\
\text { g, h, i }\end{array}$ & $\begin{array}{c}\text { "Half-things" } \\
\text { a-f }\end{array}$ \\
\hline III & $\begin{array}{c}\text { "Half-things" } \\
\text { a, b, c }\end{array}$ & - & $\begin{array}{l}\text { "Things" } \\
\text { d, e,f }\end{array}$ & $\begin{array}{c}\text { "Half-things" } \\
\text { a-f }\end{array}$ \\
\hline IV & - & - & $\begin{array}{l}\text { "Things" } \\
\text { a, b, c }\end{array}$ & $\begin{array}{c}\text { "Half-things" } \\
\text { a-f }\end{array}$ \\
\hline $\mathbf{V}$ & $\begin{array}{c}\text { "Things" } \\
\mathrm{a}, \mathrm{b}, \mathrm{c}\end{array}$ & $\begin{array}{c}\text { "Half-things } \\
\text { a-f }\end{array}$ & - & - \\
\hline
\end{tabular}


TABLE II

REACTION TO “ HALF-THINGS" BY SUBJECTS IN GROUPS I-V

\begin{tabular}{|c|c|c|c|c|c|c|c|}
\hline $\begin{array}{c}\text { Condition } \\
\text { when } \\
\text { Tested }\end{array}$ & $\begin{array}{c}\text { Group } \\
\text { of } \\
\text { Subjects }\end{array}$ & Stimuli & $\begin{array}{c}\text { Total } \\
\text { No. } \\
\text { Responses }\end{array}$ & $\begin{array}{l}\text { Successful } \\
\text { Responses }\end{array}$ & $\begin{array}{l}\text { Unsuccessful } \\
\text { Responses }\end{array}$ & $\begin{array}{c}\text { Mean } \\
\text { R.T. of } \\
\text { Successes }\end{array}$ & $\begin{array}{c}\chi^{2} \text { of } \\
\text { Success and } \\
\text { Failures }\end{array}$ \\
\hline $\begin{array}{l}\text { Post-E.C.T. } \\
\text { confusional } \\
\text { state }\end{array}$ & I & $\begin{array}{l}\text { "Half-things" seen } \\
\text { alone } \\
\text { "Half-things" whose } \\
\text { corresponding } \\
\text { "things" were seen } \\
\text { before E.C.T. }\end{array}$ & $\begin{array}{l}30 \\
30\end{array}$ & $\begin{array}{l}11 \\
21\end{array}$ & $\begin{array}{r}19 \\
9\end{array}$ & $\begin{array}{l}9 \cdot 3 \\
6 \cdot 8\end{array}$ & $(P \stackrel{6.70}{=} \cdot 01)$ \\
\hline $\begin{array}{l}\text { Post-E.C.T. } \\
\text { confusional } \\
\text { state }\end{array}$ & II & $\begin{array}{l}\text { "Half-things" seen } \\
\text { for first time } \\
\text { " Half-things" already } \\
\text { seen before E.C.T. }\end{array}$ & $\begin{array}{l}51 \\
51\end{array}$ & $\begin{array}{c}16 \\
(\mathrm{IIa}=12, \\
\mathrm{II}=4) \\
40 \\
(\mathrm{IIa}=23 \\
\mathrm{II}=17)\end{array}$ & $\begin{array}{c}35 \\
(\mathrm{IIa}=15 \\
\mathrm{II}=20) \\
11 \\
(\mathrm{IIa}=4 \\
\mathrm{IIb}=7)\end{array}$ & $\begin{array}{c}9 \cdot 1 \\
(\mathrm{II}=13 \\
\mathrm{II}=5 \cdot 2) \\
4 \cdot 9 \\
(\mathrm{II}=5 \cdot 6 \\
\mathrm{II}=43)\end{array}$ & $\left(P=\frac{23}{<\cdot 002)}\right.$ \\
\hline $\begin{array}{l}\text { Post-E.C.T. } \\
\text { confusional } \\
\text { state }\end{array}$ & III & $\begin{array}{l}\text { "Half-things" seen } \\
\text { after corresponding } \\
\text { "things" in confu- } \\
\text { sional state } \\
\text { " Half-things" already } \\
\text { seen before E.C.T. }\end{array}$ & 30 & 19 & 11 & $4 \cdot 35$ & 0 \\
\hline $\begin{array}{l}\text { Post-E.C.T. } \\
\text { confusional } \\
\text { state }\end{array}$ & IV & $\begin{array}{l}\text { "Half-things" seen } \\
\text { alone } \\
\text { " Half-things" seen } \\
\text { after corresponding } \\
\text { "things" in confu- } \\
\text { sional state }\end{array}$ & 27 & 18 & 9 & $\begin{array}{l}7 \cdot 05 \\
7 \cdot 3\end{array}$ & $\left(P^{3 \cdot 0}=\cdot 10\right)$ \\
\hline $\begin{array}{l}\text { Well } \\
\text { orientated }\end{array}$ & V & $\begin{array}{l}\text { "Half-things" seen } \\
\text { alone } \\
\text { "Half-things" seen } \\
\text { after corresponding } \\
\text { "things." }\end{array}$ & $\begin{array}{l}36 \\
36\end{array}$ & $\begin{array}{l}33 \\
34\end{array}$ & $\begin{array}{l}3 \\
2\end{array}$ & $\begin{array}{l}3.65 \\
6 \cdot 0\end{array}$ & 0 \\
\hline
\end{tabular}

and failures have been calculated and are included in Table II.

It will be seen from the responses given by Group I that out of 30 " half-things" seen alone, 11 were responded to successfully and 19 unsuccessfully, whereas out of 30 " half-things" whose corresponding "things" had been seen before E.C.T., 21 were responded to successfully and only nine unsuccessfully. If these figures are compared in a $2 \times 2$ table and submitted to the $\chi^{2}$ test for goodness of fit, the value of $\chi^{2}$ is $6 \cdot 7$, and the probability that such a distribution could be due to chance is $\cdot 01$. In addition, the mean reaction-time of the successful responses falls from 9.3 seconds for those seen alone to 6.8 seconds for those seen after their corresponding "things". In order to appreciate the importance of this point, it must be remembered that at the time at which these responses were made, the subjects had seen none of the "halfthings" before, and had no conscious recollection of having seen the "things" before treatment.
From the responses given by Groups IIa and $b$ it will be seen that out of 51 " half-things" seen for the first time after E.C.T., 16 are responded to successfully and 35 unsuccessfully, while of the same number seen already before E.C.T. 40 are responded to successfully and only 11 unsuccessfully. This distribution is again above the chance expectation. The mean reaction-time for the successful responses is also shorter for those seen before than for those seen for the first time, despite the patient's amnesia for the previous exposures. Since there is no significant difference between the successful and unsuccessful responses of Groups IIa and IIb, it must be concluded that the responses made to the three irrelevant "things" before the true postE.C.T. testing is begun (Group IIb) did not influence the reactions to the " half-things". The importance of this finding will be considered in the discussion.

The subjects in Group III gave the same numbers of successful and unsuccessful responses after E.C.T. to " half-things" already seen before E.C.T. as to 
those seen for the first time but soon after their corresponding "things". Thus, previous responses to the same stimulus before E.C.T., and to a related stimulus after E.C.T. appear to be alike in facilitating the enaction of this response during the confusional period. This point is further emphasized by the responses of Group IV, who show significantly more successful responses to "halfthings" seen for the first time but soon after their corresponding "things" after E.C.T.. than for those seen for the first time and alone.

The subjects in Group $V$ were examined in a well-orientated state, not having begun their course of E.C.T. up to the time of the experiment. Nearly all "half-things" were responded to successfully, but in contrast to the post-E.C.T. patients, who responded more readily to " half-things" seen after their corresponding "things" than to those seen alone, the subjects in Group V responded more readily to the "half-things" seen alone than to those seen after their corresponding "things". This is shown by the mean reaction-time which rises from 3.65 seconds for the former to 6.0 seconds for the latter. A possible reason for this delay was suggested by the way in which some of the patients in this group gave their responses. Thus, when shown the " half-things" corresponding to a "thing" they had already named, there was a tendency to give such responses as, "Well, it's not really a stool; it's not as good a picture as the other ", indicating that recollection of the " thing" might have set a standard in the patient's mind which impeded performance of the same reaction to a " half-thing".

\section{Discussion}

From the results quoted above, three points appear to be outstanding. (1) A verbal response aroused by one stimulus immediately before or immediately after E.C.T. is more easily aroused by a different (though related) stimulus in the confusional period than is a different verbal response. (2) The effect of the previous response is not disturbed by an interpolated task calling for a new response, such as that required by the naming of three irrelevant pictures. (3) The comparatively easier elicitation of verbal responses is not noted under conditions in which the second stimulus arouses at the same time an explicit memory of the original stimulus. Thus the reproduction of a verbal response and the memory of previous perceptions with which it was associated do appear to be separable and to substantiate the introductory hypothesis. That these two functions are also operating with different degrees of efficiency in patients suffering from amnesic states due to other organic syndromes is suggested by Bonhoeffer's observations published in 1901. Despite retroactive amnesia sometimes extending back for 20 years, he showed that patients exhibiting Korsakoff's syndrome do not revert to more juvenile behaviour but act as if they knew they were in a hospital. Gregor and Roemer (1906), studying the reaction time on simple and choice reactions in Korsakoff patients, also noted an after-effect of earlier impressions. These two observations suggest that in such patients acquired motor responses may be retained even if learned during the period to which the subject is ostensibly amnesic.

From the nature of the responses given by the subjects in the control group of the experiment reported here, it is apparent that these two aspects of memory, reproduction (performance memory) and recognition (perception memory), usually operate together. It is worth noting, however, that a perceptual memory need not necessarily be identical with the perception which established it. In fact, even in non-amnesic persons, it is very often markedly different. This point and some of the factors influencing the alterations occurring in memory images have been stressed by Bartlett (1932). The discrepancy between a memory image and the perception with which it was originally associated is often increased in organically ill patients who, as demonstrated by Zangwill (1940), may be able to describe and draw pictures which they regard as unfamiliar when shown again. Thus, the arousing of perceptual images appears to be another aspect of memory, distinct from both reproduction and recognition.

Whether these aspects of memory should be regarded as levels of function acting simultaneously in the non-amnesic person, as Gillespie (1937) suggests, or whether they should be regarded as different stages of the same function which in the non-amnesic person is carried to its full conclusion very quickly, it is difficult to say. A more detailed discussion of the influence that the above experiment may have on general theories of memory would probably be better left till after the elucidation of other outstanding points.

One such point raised by these findings is the nature of the sense of familiarity. This feeling (Claparède's " me-ness") which is usually associated with repeated stimuli, is strikingly absent in patients after E.C.T. (Zubin, 1948), and is often found to be lacking in organic amnesic states (MacCurdy, 1928). How far a sense of familiarity is directly associated with the arousing of perceptual memories, which in such cases are also disturbed, is not clear, but is a matter which could well be investigated further. 


\section{Summary}

Studies are described of the re-arousing of verbal responses by a series of pictures resembling, though not identical with, a series. of pictures seen earlier. The subjects were 46 patients undergoing E.C.T. and 12 matched controls.

It was found that patients who were asked to give a verbal response to concrete pictures before a course of E.C.T. or during the early confusional period after it, gave the same verbal response more quickly than was expected to ambiguous pictures seen in the confusional state.

In well-orientated patients exactly the opposite effects were noted. If the patients were shown concrete pictures before the ambiguous ones, the ambiguous ones were responded to more slowly than if seen alone.

The relationship between these findings and some disturbances of memory noted in cases with known organic lesions is discussed, with references to further possible lines of research.

I should like to acknowledge my gratitude to Dr. Joshua Carse, Medical Superintendent of Graylingwell Hospital, where these investigations have been carried out, for permission to publish the material, and to O. L. Zangwill for his valuable advice.

\section{REFERENCES}

Bartlett, F. C. (1932). “ Remembering." Cambridge. Bonhoeffer, K. (1901). "Die akuten Geisteskrankheiten der Gewohnheitstrinker." Jena.

Gillespie, R. D. (1937). Arch. Neurol. Psychiat., Chicago, 37, 748.

Gregor, A., and Roemer, H. (1906). Neurol. Zbl., 25, 339.

MacCurdy, J. T. (1928). "Common Principles in Psychology and Physiology", Ch. II. Cambridge.

Williams, M. (1950). Journal of Neurology, Neurosurgery and Psychiatry, 13, 30.

Zangwill, O. L. (1940). Brit. J. Psychol., 31, 230.

Zubin J., (1942). Psychol. Bull., 39, 511. -(1948). J. Personality., 17, 33. 